\title{
Sugar Palm Fruits (Arenga pinnata) as Potential Analgesics and Anti-Inflammatory Agent
}

\author{
Evi Sovia1 ${ }^{1}$, Dian Anggraeny² \\ ${ }^{1}$ Pharmacology Laboratory, Faculty of Medicine, Universitas Jenderal Achmad Yani, Cimahi, Indonesia \\ ${ }^{2}$ Histology Laboratory, Faculty of Medicine, Universitas Jenderal Achmad Yani, Cimahi, Indonesia
}

\begin{abstract}
Background: Sugar palm fruit (Arenga pinnata) is used for osteoarthritis empirically. It also has antioxidant activity and showed inhibition to lipoxygenase activity. The study about analgesic and anti-inflammatory activities of sugar palm fruit is still limited, this study was initiated to explore analgesic and anti-inflammatory effects of sugar palm fruit ethanol extract (SFEE).

Materials and Methods: Acetic acid induced writhing was performed for screening analgesic activity, meanwhile antiinflammatory activity was tested against rat paw edema. Acute toxicity and phytochemical screening were also investigated. Results: The results of phytochemical screening revealed that flavonoids, alkaloids and quinones were present in SFEE. SFEE 50 and $100 \mathrm{mg} / \mathrm{kg}$ have analgesic effect and show the anti-oedematogenic effect against paw edema induced by carrageenan. SFEE could significantly decrease the neutrophils numbers as compared to the carrageenan-treated group. Neutrophil activation has been shown to contribute to tissue inflammation and damage.
\end{abstract}

Conclusion: SFEE have analgetic and anti-inflammatory activity.

Keywords: Arenga pinnata, analgesic, anti-inflammatory, acute toxicity

\section{Introduction}

Inflammation is an essential response provided by the immune system that ensures the survival during infection and tissue injury. The classical symptoms of inflammation are redness, swelling, heat, and pain..$^{1,2}$ Therefore, there are always interactions between pain and inflammation. Nonsteroidal anti-inflammatory drugs (NSAIDs) have analgesics and anti-inflammatory effects, but they cause kinds of adverse effects during clinical use. Gastrointestinal complication is the most common side-effect, other major side effects are renal disturbances and cardiovascular events. ${ }^{3}$ NSAIDs also caused rashes, allergic reactions, pruritus, abnormal liver-associated enzymes and rarely liver failure, neutropenia, tinnitus, hypertension, dyspepsia, fluid retention, and rarely aplastic anemia. ${ }^{4}$ Therefore, the research for new analgesics and antiinflammation agents with minimal side effects are critically needed.

Medicinal plants have been used therapeutically all around the world and being an important aspect of various traditional medicine systems. ${ }^{5}$ Herbal medicines showed safety, efficacy, cultural acceptability and lesser

Date of submission: February 7, 2019

Last Revised: March 25, 2019

Accepted for publication: March 25, 2019

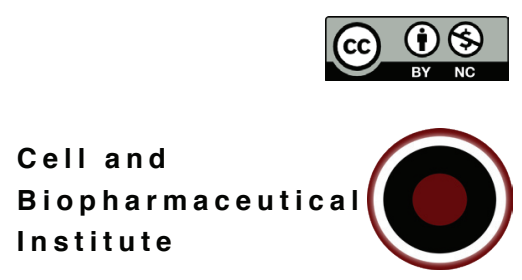

Corresponding Author:

Evi Sovia

Pharmacology Laboratory, Faculty of Medicine

Universitas Jenderal Achmad Yani

Jl. Terusan Jenderal Sudirman, Cimahi, Indonesia

e-mail: soviaevi@yahoo.com 
side effects than the synthetic drugs. The numbers of chemical compounds, found within the plant are supposed to have better compatibility with the human body. Different phytoconstituents like alkaloids, flavonoids, xanthone, coumarins, sterols, withaferin-A, and andrographolide are also proved effective as analgesic and anti-inflammatory agent. $^{6}$

Palm trees (Arenga pinnata (Wurmb) Merr.) are solitary, unarmed, pleonanthic, monoecious feather palm. Native to Southeast Asia, occurring in tropical rainforest and dry forest. Arenga pinnata is a popular plant because of its year-round food production, especially in the dry season when other food is scarce. The most important product is sweet sap, called saguer, which is used as a drink and as the raw material for sugar production. One of the parts that interest the Indonesian people is the half-cooked endosperm, which is commonly called sugar palm fruit. ${ }^{7}$ Sugar palm fruit use as analgesic and antiinflammatory agent empirically. However, the study about analgesic and anti-inflammatory activities of sugar palm fruit is still limited. Hence, this study was conducted to investigate phytochemical analysis, analgesic and anti-inflammatory activities and safety of sugar palm fruit ethanol extract (SFEE) for the purpose of developing a new drug for the treatment of inflammation and pain.

\section{Materials and methods}

\section{Drugs and Reagents}

Sugar palm fruit was obtained from local market. Acetic acid (AC) was bought from Sigma (St. Louis, USA). Potassium diclofenac (K-diclofenac) was bought from Kalbe (Jakarta, Indonesia). Carrageenan was bought from the Sigma.

\section{Animal Preparation}

Adult males (average weight $18 \pm 2$ g) Swiss Webster mice and males (average weight 180-220 g) Sprague-Dawley (SD) rats were bought from PT. Biofarma (Bandung, Indonesia). Both of them were kept in well ventilated cages in the animal laboratory Faculty of Medicine, Jenderal Achmad Yani University, Cimahi, Indonesia. Each cage contained equal number of mice or rats of the same sex. Experiments were started after the animals acclimating for a week.

\section{Ethics Statement}

All procedures involving animals and their care in this study were approved by The Health Research Ethics Committee,
Faculty of Medicine, Universitas Padjadjaran Bandung, with ethical approval No. 109/UN6.C10/PN/2017.

\section{Preparation of Extract}

Two kg of sugar palm fruit was cleaned, crushed and dried at $70^{\circ} \mathrm{C}$ temperature. The dried fruit was powdered in an electrical grinder at room temperature before the extraction process using the maceration method. About $1.3 \mathrm{~g}$ powder was mixed into $300 \mathrm{~mL}$ of $95 \%$ ethanol, and the mixture was subjected to shaking for 5-10 min every $8 \mathrm{~h}$. Then, the macerate was separated and filtered from the dregs. The maceration process was repeated until the macerate was clear. The ethanol extract was concentrated using rotary evaporator (Buchi, Essen, Germany). ${ }^{8}$

\section{Phytochemical Screening}

Chemical tests were carried out on SFEE for the qualitative determination of phytochemical constituents as per standard procedures. ${ }^{9}$ Firstly was the detection of alkaloids. About $1 \mathrm{~g}$ of extract was mixed with $5 \mathrm{~mL}$ of dilute ammonia and then crushed in a mortar, then added $20 \mathrm{~mL}$ of chloroform while continuing to be crushed. Then filtered, the filtrate was put into the test tube and then added $5 \mathrm{~mL}$ of $2 \mathrm{~N}$ hydrochloric acid. The mixture was shaken vigorously until it forms 2 layers. The acid layer is separated then divided into 3 parts. The first part is used as blank. The second part treated with 2-3 drops of Mayer reagent, formation of white precipitate indicates the presence of alkaloids. The third part treated with 2-3 drops of Dragendorf reagent, formation of red precipitate indicates the presence of alkaloids.

Secondly was the detection of flavonoids. About 1 $\mathrm{g}$ of extract was heated with a water bath, then filtered. A total of $5 \mathrm{~mL}$ of filtrate was put into a test tube then added magnesium powder and $1 \mathrm{~mL}$ of $2 \mathrm{~N}$ hydrochloric acid. The mixture was heated over a water bath, then filtered. The resulting filtrate was orange, then put in a test tube and added $5 \mathrm{~mL}$ of amyl alcohol. The mixture was then shaken strong and allowed to separate. The amyl alcohol layer turns brownish red indicating that the extract contains flavonoids.

The next step was the detection of tannins and polyphenol $1 \mathrm{~g}$ extract heated with water bath, then filtered. The filtrate was divided into 2 equal parts. The first part treated with 2-3 drops of iron (III) chloride reagent solution, formation of black-green precipitate indicates the presence of natural polyphenols. The second part was retested with the addition of 5 drops of $1 \%$ gelatin. Formation of white precipitate indicates the presence of tannins. 
The next was the detection of saponins. The extract was stored in a test tube which is above the water bath and then mixed with water and heated for a while, then filtered. After the extract is cool, the filtrate is shaken vigorously for 30 seconds. If foam produced persists for ten minutes it indicates the presence of saponins.

Lastly was the detection of quinones. A total of $1 \mathrm{~g}$ of extract was heated with a water bath, then filtered. The filtrates were treated with 2-3 drops of $\mathrm{KOH}$ solution. The formation of a solid red color precipitate indicates the presence of quinones.

\section{Acute Toxicity Study}

Mice were kept on overnight fasting and water was withheld for 3-4 $\mathrm{h}$ before the administration of the test compound. Following the period of fasting, the animals were weighed and divided into five groups, three mice in each group. The negative control group received carboxymethylcellulose $0.5 \%$ by gavage while the treatment groups received SFEE in a dose of 50,300, 2000 and $5000 \mathrm{mg} / \mathrm{kg}$. Immediately after dosing, the mice were observed continuously for 4 $\mathrm{h}$ for symptoms of toxicity like motor activity, tremors, convulsions, tonic extension, muscle spasm, loss of righting reflex, ataxia, sedation, hypnosis, lacrimation, diarrhea, salivation and writhing. Mice were then kept under observation up to $24 \mathrm{~h}$ for any mortality. Body weight and chow consumption of mice were recorded for 14 days. ${ }^{10}$ On day 15 mice were terminated, a comprehensive gross observation was carried out on the internal organs, such as the liver, spleens, pulmonal, heart, and kidneys. They were observed for any signs of abnormality and for the presence of lesion owing to any effect of the SFEE administration. The organs were then carefully dissected, cleaned of any fats and weighed. The relative organ weight (ROW) of each organ was then calculated according to the following equation $^{11}$ :

$$
\mathrm{ROW}=\frac{\text { (absolute organ weight }(\mathrm{g}) \times 100)}{\text { body weight of mice on sacrifice day }(\mathrm{g})}
$$

\section{Analgesic Assay}

Acetic Acid-Induced Abdominal Writhing Test. Twenty males' mice were randomly divided into four groups. The mice were treated with $0.5 \%$ carboxymethylcellulose, 50 and $100 \mathrm{mg} / \mathrm{kg}$ dose of SFEE and K-diclofenac (10 $\mathrm{mg} / \mathrm{kg}$ ), respectively. The mice were orally treated. After administrated for $1 \mathrm{~h}$, the mice in each group were intraperitoneally injected with $0.1 \mathrm{~mL} / 10 \mathrm{~g}$ acetic acid. ${ }^{12}$ Then, the number of writhes (n) within $30 \mathrm{~min}$ (writhe reactions including abdominal contractions, stretching of hind paws, writhing of abdominal muscles, and times of hips up) after acetic acid injection were recorded..$^{13}$ The analgesic percentage was calculated as follows ${ }^{14}$ :

Inhibition rate $\%=\mathrm{n}$ writhes $($ control $)-\mathrm{n}$ writhes $($ treated $) \times 100 \%$ $\mathrm{n}$ writhes (control)

\section{Anti-inflammatory Assay}

Anti-inflammatory activities of SFEE was studied by carrageenan induced paw edema model in rats. Twenty males rats were randomly divided into four groups. The rats were treated with $0.5 \%$ carboxymethylcellulose (control group), 50 and $100 \mathrm{mg} / \mathrm{kg}$ dose of SFEE, and K-diclofenac $(10 \mathrm{mg} / \mathrm{kg})$, respectively. The rats were orally treated once. After 30 min of the treated, the left hind paw of each rats was injected subcutaneously with $50 \mu \mathrm{L}$ carrageenan $(1 \%$, w/v saline). Paw volume was measured using a plethysmometer at $0^{\text {th }}, 1^{\text {st }}, 2^{\text {nd }}, 3^{\text {rd }}$ and $4^{\text {th }} \mathrm{h}$ after treatment. After $4 \mathrm{~h}$, the animals were euthanized. Their right and left paws were removed and weighed in an electronic analytical balance. This following formula was used:

$$
\% \text { edema inhibition }=[1-(\mathrm{Vt} / \mathrm{Vc})] \times 100
$$

The percent inhibition of the inflammation was calculated using the formula and compared with control group. ${ }^{15} \mathrm{Vt}$ and $\mathrm{Vc}$ are edema volume in the drug treated and control groups respectively.

\section{Histological Examination}

For histological examination, biopsies of paws were taken $5 \mathrm{~h}$ following the injection of carrageenan. The tissue slices were fixed in (1.85\% formaldehyde, $1 \%$ acetic acid) for 1 week at room temperature, dehydrated by graded ethanol and embedded in Paraffin. Sections (thickness 5 $\mu \mathrm{m})$ were deparaffinized with xylene and stained with $\mathrm{H}$ (Haematoxyllin) \& E (Eosin) stain.

All samples were observed and photographed with Olympus microscopy. Every three tissue slices were randomly chosen from carrageenan, SFEE treated (50 and $100 \mathrm{mg} / \mathrm{kg}$ ) and $\mathrm{K}$-diclofenac groups. The numbers of neutrophils were counted in each scope (400x) and thereafter obtain their average count from five scopes of every tissue slice. 


\section{Statistical Analysis}

Means and standard deviations were calculated. The statistical significance $(p<0.05)$ was compared among the control and experimental groups by using analysis of variance (ANOVA) followed by the Tukey test.

\section{Results}

\section{Phytochemical Screening}

The results of phytochemical screening revealed that alkaloids, flavonoids and quinones were present in SFEE. The chemical compounds could be playing important role in exhibited pharmacological effects.

\section{Acute Toxicity}

Acute toxicity test results showed that SFEE acute administration with 50, 300, 2000 and $3000 \mathrm{mg} / \mathrm{kg}$ doses did not cause mortality in animal experiment. According to The Organisation for Economic Co-operation and Development (OECD) guidelines, SFEE falls in category-5 having $\mathrm{LD}_{50} 5000 \mathrm{mg} / \mathrm{kg} \mathrm{10}$. Body weights after 14 days single administration of SFEE increase significantly $(p<0.05)$. The control group also shows increasing in body weight (Table 1). This results suggested that SFEE acute administration have no effect to body weight. Relative organ weight (ROW) of heart, liver, lung and spleen of treated mice were found to be well within the limit. However, ROW of renal in SFEE $5000 \mathrm{mg} / \mathrm{kg}$ group decrease significantly $(p<0.05)$ (Table 2$)$.

\section{Analgesics Effects of SFEE}

As shown in Table 3, SFEE and K-diclofenac treated groups were all significantly reduced the number of writhes compared with the control group $(p<0.01)$. The inhibition

Table 1. Body weights of control and SFEE treated groups before and after single administration of SFEE with 50, 300, 2000 and $5000 \mathrm{mg} / \mathrm{kg}$ doses.

\begin{tabular}{llll}
\hline \multirow{2}{*}{ Groups } & \multicolumn{2}{c}{ Body Weights (g) } & \multirow{2}{*}{-value } \\
\cline { 2 - 3 } & Before & After & \\
\hline Control & $28 \pm 2.7$ & $39 \pm 4.2$ & $0.004^{*}$ \\
SFEE $50 \mathrm{mg} / \mathrm{kg}$ & $29 \pm 4.2$ & $37 \pm 2.7$ & $0.035^{*}$ \\
SFEE $300 \mathrm{mg} / \mathrm{kg}$ & $28 \pm 2.9$ & $38 \pm 2.9$ & $0.000^{*}$ \\
SFEE $2000 \mathrm{mg} / \mathrm{kg}$ & $27 \pm 2.7$ & $40 \pm 3.5$ & $0.000^{*}$ \\
SFEE $5000 \mathrm{mg} / \mathrm{kg}$ & $26 \pm 4.2$ & $39 \pm 2.2$ & $0.003^{*}$ \\
\hline
\end{tabular}

${ }^{*} p<0.05$ : body weight before treatment compare to after treatment using paired t-test. SFEE: sugar palm fruit ethanol extract; control group given carboxymethylcellulose. rates in SFEE 50 and $100 \mathrm{mg} / \mathrm{kg}$ treated (62.2\% and 68.5\%) was higher than that in the $\mathrm{K}$ - diclofenac treated group $(35.5 \%)$. This indicates that SFEE have a potent analgesic effect, and SFEE shows better activity than K-diclofenac. Results of post hoc Tukey showed significant difference $(p<0.05)$ between inhibition rate of SFEE 50 and $100 \mathrm{mg} / \mathrm{kg}$ compared with K-diclofenac $10 \mathrm{mg} / \mathrm{kg}$.

\section{Anti-inflammatory Effects of SFEE}

In this study, paw edema volume in mice were significantly reduced after administration of SFEE. However, SFEE 50 and $100 \mathrm{mg} / \mathrm{kg}$ and K-diclofenac $10 \mathrm{mg} / \mathrm{kg}$ showed significant $(p<0.05)$ reduction in paw edema volume after 4th $\mathrm{h}$ and had no significant reduction effects after the 1-3 $\mathrm{h}$ time point (Figure 1A). The inhibition rate in the SFEE 50 and $100 \mathrm{mg} / \mathrm{kg}$ were $52.4 \%$ and $63.5 \%$, respectively and in the Ka-diclofenac was $52.1 \%$ (Figure 1B). It was suggested that SFEE possessed an anti-inflammatory and the activity was the same with that of K-diclofenac as a positive control. Paw biopsies of negative control group animals showed marked cellular infiltration in the connective tissue. The infiltrates accumulated between collagen fibers and into intercellular spaces. Paw biopsies of animals treated with SFEE (50 and $100 \mathrm{mg} / \mathrm{kg}$ ) showed a reduction in carrageenan-induced inflammatory response. Actually inflammatory cells were reduced in number and confined near to the vascular areas. Intercellular spaces did not show any cellular infiltrations (Figure 2). Neutrophils were increased with carrageenan treatment $(p<0.01)$. K-diclofenac and SFEE can significantly decrease the number of neutrophils compared to the carrageenan-treated group ( $p<0.01)$ (Table 4).

\section{Discussion}

There was no study about phytochemical compounds of sugar palm fruit, however previous study showed that sugar palm midrib flour contain alkaloids, triterpenoids and tannin. ${ }^{16}$ Date fruit, that also belongs to palmae family contain ascorbic acid, carotenoids, flavonoids and polyphenols. ${ }^{17}$ Alkaloids and flavonoids are the important chemical compounds in causing analgesic and antiinflammatory effects. Previous studies have demonstrated the analgesic activity of alkaloids derived from Ziziyphus nummularia, Myristica fragrans and Gelsemium. ${ }^{18}$ Alkaloids also exhibit anti-inflammatory effects, isoquinoline type was the most studied. ${ }^{18}$ Meanwhile, the mechanisms of action of flavonoids as analgesic and anti-inflammatory are inhibition 
Table 2. Relative organ weight (ROW) of control and SFEE treated groups on day $14^{\text {th }}$ after single administration of SFEE with $50,300,2000$ and $5000 \mathrm{mg} / \mathrm{kg}$ doses.

\begin{tabular}{|c|c|c|c|c|c|c|c|c|c|c|}
\hline \multirow{2}{*}{ Groups } & \multicolumn{2}{|c|}{ Liver } & \multicolumn{2}{|c|}{ Spleen } & \multicolumn{2}{|c|}{ Renal } & \multicolumn{2}{|c|}{ Heart } & \multicolumn{2}{|c|}{ Lung } \\
\hline & ROW (g) & $p$-value & ROW (g) & $p$-value & ROW (g) & $p$-value & ROW (g) & $p$-value & ROW (g) & p-value \\
\hline Control & $6.364 \pm 1.05$ & 0.989 & $0.472 \pm 0.11$ & 0.571 & $2.0 \pm 0.18$ & $0.031^{*}$ & $0.612 \pm 0.09$ & 0.074 & $0.746 \pm 0.09$ & 0.320 \\
\hline SFEE $50 \mathrm{mg} / \mathrm{kg}$ & $6.546 \pm 0.41$ & & $0.562 \pm 0.21$ & & $1.948 \pm 0.12$ & & $0.636 \pm 0.11$ & & $0.724 \pm 0.13$ & \\
\hline SFEE $300 \mathrm{mg} / \mathrm{kg}$ & $6.420 \pm 0.24$ & & $0.425 \pm 0.08$ & & $1.852 \pm 0.09$ & & $0.668 \pm 0.13$ & & $0.630 \pm 0.27$ & \\
\hline SFEE $2000 \mathrm{mg} / \mathrm{kg}$ & $6.544 \pm 0.81$ & & $0.424 \pm 0.08$ & & $1.878 \pm 0.20$ & & $0.546 \pm 0.05$ & & $0.702 \pm 0.94$ & \\
\hline SFEE $5000 \mathrm{mg} / \mathrm{kg}$ & $0.653 \pm 0.43$ & & $0.520 \pm 0.20$ & & $1.658 \pm 0.17$ & & $0.506 \pm 0.46$ & & $0.626 \pm 0.14$ & \\
\hline
\end{tabular}

$* p<0.05$ : versus vehicle treated control using one-way ANOVA followed by Tukey's post hoc multiple-comparison test. SFEE: sugar palm fruit ethanol extract.

of cytokine production or cytokine-dependent inflammation and inhibit the peroxidase active site of COX-1, COX-2, and 5-lipoxygenase (5-LO). ${ }^{19}$

The acute toxicity results of this study differ from the previous study on an ethanol extract of palm sugar flour which showed $\mathrm{LC}_{50}$ value of $6,295 \mathrm{ppm}$ included in toxic category. ${ }^{16}$ Sugar palm fruits contain $6.8 \%$ moisture, $7.9 \%$ ash, $16.2 \%$ crude fibre, $10 \%$ crude protein and $1.5 \%$ fat. It is used for a cocktail and local refreshment known as kolak. ${ }^{20}$ SFEE effect on the kidneys need further research such as microscopic examination and blood ureum and creatinin level.

Inflammation is a complex biological response due to different harmful stimuli. Inflammation with pain is associated with different diseases like rheumatism, encephalitis, pneumonia, esophagitis, cancer, heart problems, fibrosis, etc. NSAIDs and opioid analgesic are used in the treatment of inflammation and pain, however they can cause a lot of adverse effect. Hence, the medicinal plants have been considered as a source of medicines for therapeutic applications. ${ }^{6}$

In this study, writhing test was used to evaluate analgesic activity of SFEE. Writhing test is a chemical method used to induce pain of peripheral origin by injection of irritant principles like phenylquinone, acetic acid in mice. Analgesic activity of the test compound is inferred from decrease in the frequency of writhing. ${ }^{21}$ This study shown that SFEE have analgesics effects. The analgesic effect is probably caused by its mechanism of action in inhibiting lipoxygenase. $^{?}$

To assess the anti-inflammatory properties of SFEE, carrageenan induced paw edema was used. This model is based on the principle of release of various inflammatory mediators by carrageenan. Edema formation due to carrageenan in the rat paw is biphasic event. The initial phase $(0-2 \mathrm{~h})$ is attributed to the release of histamine and serotonin. The second phase of edema $(2-5 \mathrm{~h})$ is due to the release of prostaglandins, protease and lysosome. Subcutaneous injection of carrageenan in to the rat paw produces inflammation resulting from plasma extravasation, increased tissue water and plasma protein exudation along with neutrophil extravasation, all due to the metabolism of arachidonic acid. ${ }^{15}$ The results of this study shown antiinflammatory effects of SFEE. This result was relevant with the existing finding that SFEE could inhibit inflammation due to lipoxygenase inhibition.?

Table 3. Number of writhes and inhibition rate control and treated groups after acetic acid induced.

\begin{tabular}{lcccc}
\hline \multicolumn{1}{c}{ Groups } & $\begin{array}{c}\text { Count of Writhes } \\
(\text { Mean } \pm \text { SD) }\end{array}$ & $\boldsymbol{p}$-value & $\begin{array}{c}\text { Inhibition Rate } \\
(\%)\end{array}$ & $\boldsymbol{p}$-value \\
\hline Control & $25.5 \pm 6.4$ & $0.00^{*}$ & 0 & $0.03^{*}$ \\
SFEE $50 \mathrm{mg} / \mathrm{kg}$ & $9.5 \pm 2.1$ & & $62.2 \pm 5.4$ & \\
SFEE $100 \mathrm{mg} / \mathrm{kg}$ & $7.3 \pm 1.7$ & & $68.5 \pm 15.5$ & \\
K-diclofenac $10 \mathrm{mg} / \mathrm{kg}$ & $15.7 \pm 3.3$ & & $35.5 \pm 20.4$ & \\
\hline
\end{tabular}

${ }^{*} p<0.05$ : versus vehicle treated control using one-way ANOVA followed by Tukey's post hoc multiple-comparison test. SFEE: sugar palm fruit ethanol extract. 

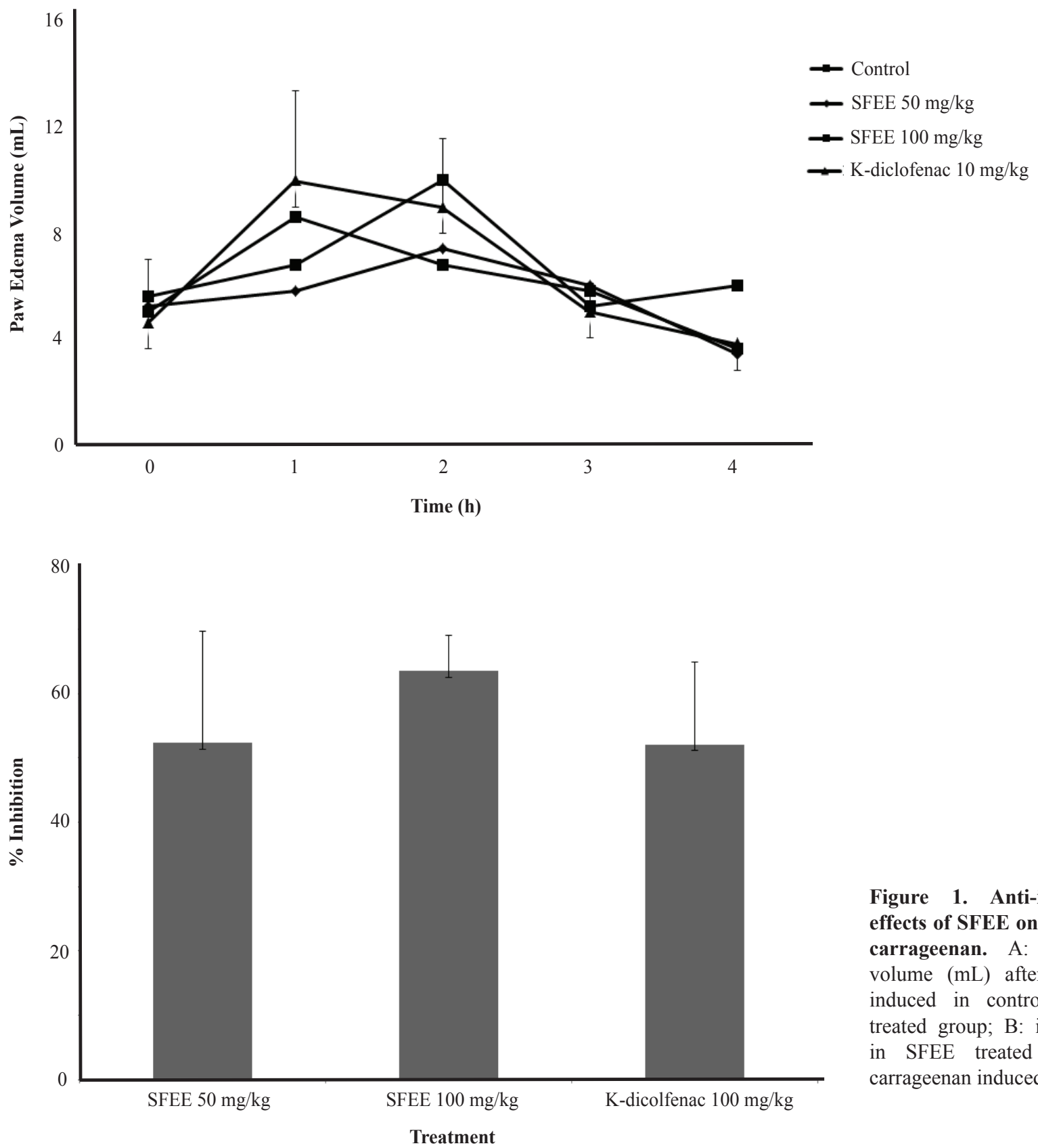

Figure 1. Anti-inflammatory effects of SFEE on paw induced carrageenan. A: paw edema volume $(\mathrm{mL})$ after carrageenan induced in control and SFEE treated group; B: inhibition rate in SFEE treated group after carrageenan induced paw edema.

The carrageenan-induced inflammatory response has been linked to neutrophils infiltration. ${ }^{22}$ Neutrophils use myeloperoxidase (MPO) to mediate many of their multifaceted functions that they have in the immune system. MPO release and subsequent formation of hypochlorous $(\mathrm{HOCl})$ in the extracellular environment following neutrophil activation have been shown to contribute to tissue inflammation and damage. ${ }^{23}$ Anti-inflammatory effects of SFEE due to its ability to decreased neutrophils number.
Table 4. Numbers of neutrophils in control and treated groups that count in each scope (400x) and thereafter obtain their average count from five scopes of every tissue slice.

\begin{tabular}{lcc}
\hline \multicolumn{1}{c}{ Groups } & $\begin{array}{c}\text { Number of Neutrophlis } \\
\text { (Mean } \pm \text { SD) }\end{array}$ & $\boldsymbol{p}$-value \\
\hline Control & $13.7 \pm 4$ & $0.003^{*}$ \\
SFEE $50 \mathrm{mg} / \mathrm{kg}$ & $9.7 \pm 1.5$ & \\
SFEE $100 \mathrm{mg} / \mathrm{kg}$ & $8.9 \pm 4.4$ & \\
K-diclofenac $10 \mathrm{mg} / \mathrm{kg}$ & $4.3 \pm 1.2$ & \\
\hline
\end{tabular}

$* p<0.05$ tested with ANOVA. 

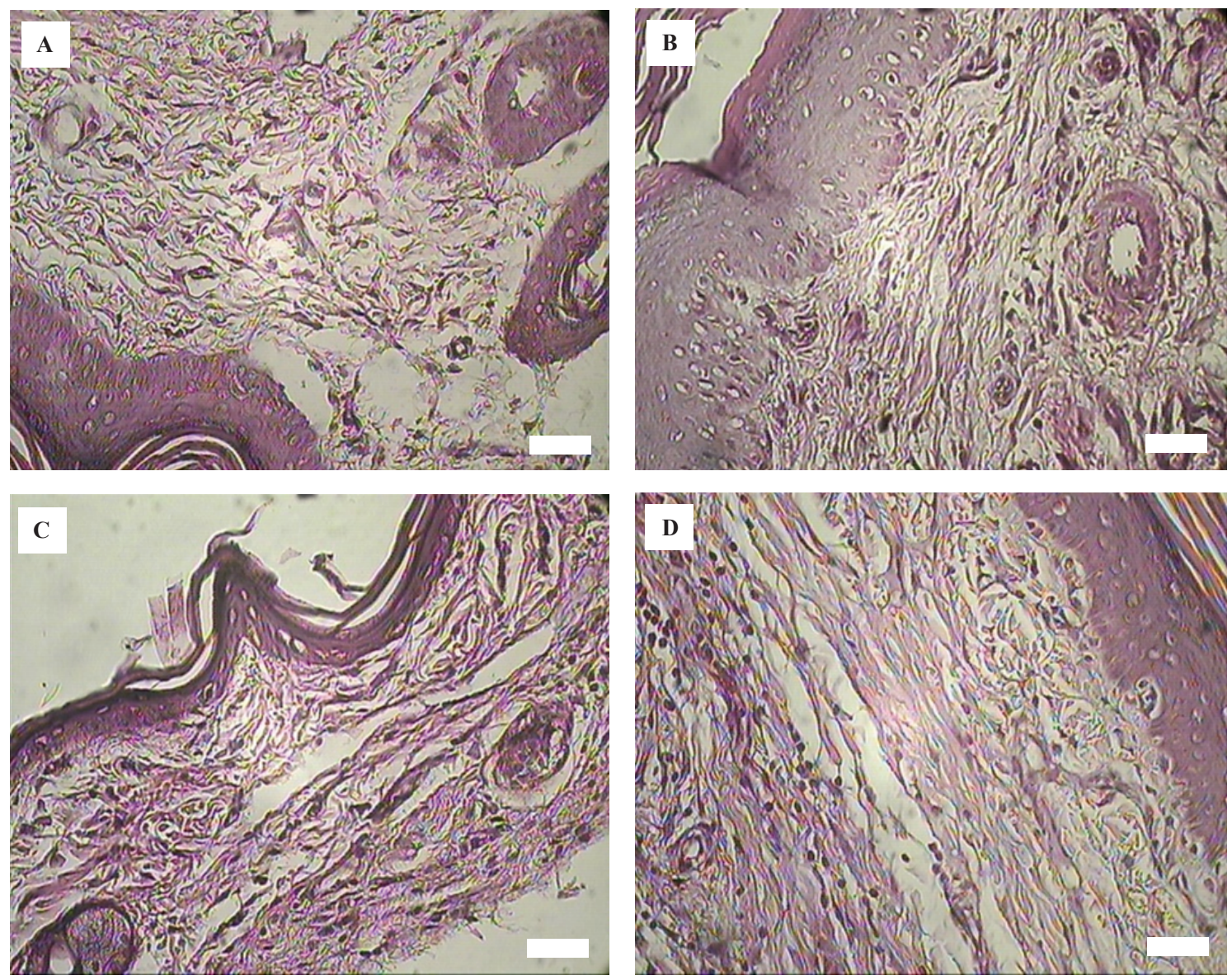

Figure 2. Histological appearance of the rat hind foot after a subcutaneous injection with carrageenan stained with $H \& E$ stain. A: hemorrhage with moderately extravascular red blood cell and large amount of inflammatory leukocyte mainly neutrophils infiltration in the subdermis interstitial tissue of rats following the subcutaneous injection of carrageenan only; B,C: SFEE show morphological alterations compared to subcutaneous injection of carrageenan only; D: K-diclofenac reduced the level of hemorrhage, edema and inflammatory cell infiltration compared to subcutaneous injection of carrageenan only $(400 \mathrm{x})$. White bar: $10 \mu \mathrm{m}$.

\section{Conclusion}

SFEE contains flavonoids, alkaloids and quinones that might be playing important role in exhibited analgesic and anti-inflammatory activity. SFEE could be used as a pharmacological agent in the prevention or treatment of disease in which inflammation is a pathogenic factor. It is also safe for acute administration.

\section{References}

1. Swieboda P, Filip R, Prystupa A, Drozd M. Assessment of pain: types, mechanism and treatment. Ann Agric Environ Med. 2013; Special Issue 1: 2-7.

2. Ahmed AU. An overview of inflammation: mechanism and consequences. Front Biol China. 2011; 6(4): 274-81.

3. Harirforoosh S, Asghar W, Jamali F. Adverse effects of nonsteroidal antiinflammatory drugs: an update of gastrointestinal, cardiovascular and renal complications. J Pharm Pharm Sci. 2013; 16(5): 821-47.
4. Slater D, Kunnathil S, McBride J, Koppala R. Pharmacology of nonsteroidal anti-inflammatory drugs and opioids. Semin Intervent Radiol. 2010; 27(4): 400-11.

5. World Health Organization. WHO Guidelines for Assessing Quality of Herbal Medicines with Reference to Contaminants and Residues. Geneva: WHO; 2007.

6. Sen S, Chakraborty R, Biplab De, Ganesh T, Raghavendra HG, Debnath S. Analgesic and anti-inflammatory herbs: a potential source of modern medicine. Int J Pharm Sci Res. 2010; 1(11): 3244.

7. Elya B, Puspitasari N, Sudarmin AC. Antioxidant activity and inhibition of lipoxygenase activity ethanol extract of endosperm Arenga pinnata (Wurmb) Merr. Asian J Pharm Clin Res. 2017; 10(Special Issue October); 23102. doi: 10.22159/ajpcr.2017. v10s5.23102.

8. Pauli GF, Pro SM, Friesen JB.D. Countercurrent separation of natural products. J Nat Prod. 2008; 71(8): 1489-508.

9. Tiwari P, Kumar B, Kaur M, Kaur G, Kaur H. Phytochemical screening and extraction: a review. Int Pharm Sci. 2011; 1(1): 98106.

10. Badan Pengawas Obat dan Makanan RI. Peraturan Kepala Badan Pengawas Obat dan Makanan Republik Indonesia Nomor 7 Tahun 
2014 Tentang Pedoman Uji Toksisitas Nonklinik Secara in vivo. Jakarta; BPOM: 2014.

11. Samat S, Nor NAM, Nor Hussein F, Ismail WIW. Effects of gelam and acacia honey acute administration on some biochemical parameters of Sprague Dawley rats. BMC Complement Altern Med. 2014; 14(1): 146. doi:10.1186/1472-6882-14-146.

12. Le Bars D, Gozariu M, Cadden SW. Animal models of nociception. Pharmacol Rev. 2001; 53(4): 597-652.

13. Deciga-Campos M, González-Trujano E, Navarrete A, Mata R. Antinociceptive effect of selected mexican traditional medicinal Species. Proc West Pharmacol Soc. 2005; 48: 70-2.

14. Wang G, Hu Z, Song X, Cui Q, Fu Q, Jia R, et al. Analgesic and anti-inflammatory activities of resveratrol through classic models in mice and rats. Evid Based Complement Altern Med. 2017: 2017; 5197567. doi:10.1155/2017/5197567.

15. Hariram Nile S, Won Park S. Optimized methods for in vitro and in vivo anti-inflammatory assays and its applications in herbal and synthetic drug analysis. Mini Rev Med Chem. 2013; 13(1): 95-100.

16. Sangi M, Momuat L, Kumaunang M. Uji toksisitas dan skrining fitokimia tepung gabah pelepah aren (Arenga pinnata). J Ilm Sains. 2012; 12(2): 127-34.

17. Al-dawah NKJ, Ibrahim SL. Phytochemical characteristics of date palm (Phoenix dactylifera) fruit extracts. Pakistan J Food Sci. 2012; 22(3): 117-27
18. Barbosa-Filho JM, Piuvezam MR, Moura MD, Silva MS, Batista Lima KV, Leitau EV, et al. Anti-inflammatory activity of alkaloids: a twenty-century review. Brazilian J Pharmacol. 2006; 16(1): 10939.

19. Verri WA, Vicentini FTMC, Baracat MM, Georgetti SR, Cardoso DR, Cunha TM, et al. Flavonoids as anti-inflammatory and analgesic drugs: mechanisms of action and perspectives in the development of pharmaceutical forms. Bioactive Natural Product. 2012; 36: 297 330.

20. Agroforestry Database [Internet]. Arenga Pinnata (Wurmb.) Merr Arecaceae [updated 2009; cited 2018 Oct 20]. Available from: http://www.worldagroforestry.org/treedb/AFTPDFS/Arenga pinnata.PDF.

21. Gawade S. Acetic acid induced painful endogenous infliction in writhing test on mice. J Pharmacol Pharmacother. 2012; 3(4): 348. doi:10.4103/0976-500X.103699.

22. Chang HY, Sheu MJ, Yang CH, Lu TC, Chang YS, Peng WH, et al. Analgesic effects and the mechanisms of anti-inflammation of hispolon in mice. Evid Based Complement Altern Med. 2011; 2011: 478246. doi:10.1093/ecam/nep027.

23. Odobasic D, Kitching R, Holdsworth SR. Neutrophil-mediated regulation of innate and adaptive immunity: the role of myeloperoxidase immunity: the role of MPO. J Immunol Res. 2016; 2016: 2349817. doi:10.1155/2016/2349817. 